https://doi.org/10.46344/ibino.2020.v09i5b.22

\title{
REVIEW ARTICLE ON RAKTAMOKSHANA- THE MIRACULOUS THERAPY
}

Dr. Mrunali Chavan \& Dr. Deepali Amale

PG Scholar, Rog Nidan Deptt, CSMSS Ayurved College, Aurangabad Prof \& HOD, Rognidan Deptt, CSMSS Ayurved College, Aurangabad

\begin{abstract}
The rapid modernization in India, fast food culture, stressful and speedy life, prevalent in urban areas is spreading its wings in remote villages too. Nowadays human beings are vulnerable to many disorders due to their altered life style and food habits. Considering the importance of Rakta in the causation and transmission of various diseases, Sushruta has considered rakta as fourth dosa. Dushtarakta is more distressing and common disorder prevalent in present era. It is characterized by severe pain, tenderness, inflammation and burning sensation in the affected area etc. Sedentary lifestyle along with mental stress, consumption of non-vegetarian and highly protein diet, excessive alcohol intake are some of the precipitating factors which causes acute exacerbation of vitiated rakta disorders. By shodhanachikitsa it can be cure and prevented. Raktamokshana, in simple words is the procedure of allowing the blood to bleed for therapeutic purposes. The other Panchakarmas eliminates the morbid dosha, while raktamokshana eliminate the vitiated Rakta, along with rakta, pitta is also likely to be eliminated as both these are interlinked. The utility and significance of Raktamokshana is unique through which number of diseases can be relieved.
\end{abstract}

\section{No: of References: 07}




\section{INTRODUCTION:}

Ayurveda has probably given the first detailed, rational, systematic description of raktamokshana for several illnesses. It is also considered one among shodhana (purificatory) procedures. Raktamokshan means letting of blood which is mainly indicated in certain disease state especially when there is a Raktadushti and also during physiological function. ["] Sushruta, Father of Indian Surgery, has given all the information regarding bloodletting in detail in his treatise "Sushruta Samhita". [2]

To expel out the vitiated blood, seven procedures were advocated: Venesection( Sira vedhan ) Horn application ( Sringa avacharana) Gourd application ( Alabu avacharana) Leech application ( Jalauka avacharana ) Scrapping ( Prachana Karma) Cupping glass application (ghati yantra avacharana ) Needle application ( Suchi avacharana ) [3]

Main function of Rakta Dhatu is provided life i.e. Jeevan to living beings, Any fluctuations i.e. reduction or increase in its quantity may lead to various pathology. Hence to relieve the patients from these pathologies Rakta mokshana (bloodletting) is advocated as the supreme mode of treatment in our classics. Sira vedha (Venesection) is considered in some instances as half of the treatment of Shalyatantra itself. Raktamokshana Karma provides 'Ashu Vyadhya Shanti' as mentioned by Acharya Susruta as diseases do not get pacified so quickly and fully by therapeutic management like lepan etc as by siravedhana or raktamokashana. Acharya sushrut has cited that the person who regularly undergoes bloodletting will not get affected by shopha, twak dosha, visarpa, granthi etc disorders. [4]

AIMS \& OBJECTIVES:
1) To explain the effect of Raktamokshana in terms of ayurvedic parameters.

2) To explain the effect of Raktamokshana in terms of modern parameters.

\section{MATERIAL AND METHODS:}

1) Literature review from Samhitas.

2) Literature review from Modern Text.

\section{REVIEW OF LITERATURE TYPES OF RAKTAMOKSHANA:}

Two type

1. Shastra visravana -Generally metallic instrument are used to carried out the this process. It is further divided into two category- Pracchana which means letting the blood pass through several incision and Siravyadhana, which is also known as venipuncture.

2. Anushastra visravana- The metallic instrument are not considered for carrying out this procedure. It is further divided into 3 categories:-

(1) Jalaukavacharana, which mean applying leeches on a particular area. This is mainly done for pitta dosha disorder.

(2) Alabu, which mean creating vaccum \& extracting blood through the vaccum using a vegetable, which may be bottle guard or alabu. This is mainly done for treating the kapha dosha diseases.

(3) Shrungavacharana, which mean applying the cow's horns. This is mainly used for treating the vata disorder.

\section{INDICATIONS OF RAKTAMOKSHANA THERAPY ARE [5][6]}

Individuals with aggravated rakta and pitta dosha \& high level of toxicity are recommended the raktamokshana therapy. The important diseases \& complication to be treated with this

2020 September Special Issue Edition |www.jbino.com | Innovative Association 
therapeutic therapy are-Gout, Eczema, Psoriasis, Filariasis, Glaucoma, Liver \& spleen disorder, Osteoarthritis, Rheumatoid arthritis, Cellulites, Sciatica, Varicose Veins, Rheumatic Disease, Diabetic Wound, abscesses, Hypertension, Thrombosis (blood clot), Alopecia and Herpes zoster.

\section{PROCEDURE OF RAKTAMOKSHANA [5-7]}

Raktamokshana, the specialized detoxification process camprises the following steps

1. Preprocedure or poorva karma.

2. Main procedure or pradhana karma.

3. Post procedure or paschat karma.

\section{PURVA KARMA:}

It is preparatory phase before going to main karma. In this all the material should collected well eg cottan swab, gauze piece, instrument, gloves etc.

\section{PRADHANA KARMA:}

The various procedure can be considered under pradhana karma.

- PRACHHANA-This method helps to provide relief from stress, tension and anxiety.

- SIRAVYADHA-The patient either lies or sit in erect position. According to the disease the vein is selected. Then after proper oleation and sudation, the liquid gruel is injected. The size shoud be that of I brihi or half barley pramana in muscular area.

- JALAUKAVACHARANA-Small tiny sized nicks are applied near the affected region. As soon as the the blood oozes out.the leech is applied.its mouth is covered with a wet cottan cloth. After sucking of impure blood the leech will leave the area on its own.In any case when it does not leave its own then turmeric powder is sprinkled on the leech. - SHRINGA YANTRA-The horn is applied on the fleshy part of the body in this a vaccum area has been created by which blood is oozes out. PASCHAT KARMA: After completion of pradhana karma,dressing is done with medicated oils.

\section{MODERN CONCEPT:}

The extraction of blood for the cure of many disorders was in practice since antiquity until the late 19th century. In the good olden days, the physicians believed that for treating hypertension, bloodletting could sometimes have had a beneficial effect by reducing blood volume. Hippocrates was Dr.Deepika Sethi et. al., A Review Article on Raktamokshana and Its Mode of Action, IJPAAM 2018. also reported that bloodletting was in practice in Greece during the fifth century B.C. It was used to "treat" a wide range of diseases, becoming a standard

treatment for almost every ailment, and was practiced prophylactically as well as therapeutically.

\section{CONCLUSION:}

Raktamokshana is one procedures among panchkarma which aims at excreting vitiated blood (Dushta rakta) from the body. Rakthamokshana means the procedure of blood letting for the therapeutic purpose for removing morbid doshas with blood or it can practised in blood born diseases, in pitta predominant diseases and also in a few vata disorders. This therapy in ayurveda is a partial or a complete treatment depending on the situation. It explained thousands of years ago and still holds an important place in ayurvedic treatment in curing many diseases, and have become a necessity in todays world due to changing food habits and lifestyle, for 
curing ailments and also to maintain health.One who timely performs Raktamokshana never suffers from skin diseases, and other Raktaja vyadis mentioned above.

\section{REFERENCES:}

1. Sushruta. Sushruta Samhita - Ayurveda tattva sandipika commentary by $\mathrm{Dr}$ Ambika Datta Shastri, sutra sthana published by Chaukhambha samskrit samsthan, Varanasi; p. 43-46.

2. Sushruta. Sushruta Samhita. Text with English Translation \& Notes, Sutra Sthana, 1 st Ed. Varanasi: Chaukambha Visvabharati; 2004.p.134-42.

3. Sathish HS, Vaghela DB. Bloodletting An Ayurvedic Perspective, Letter to the Editor. Journal of Postgraduate Medicine 2011;

57(3).http://dx.doi.org/10.4103/00223859.85223.PMid:21941072
4. Sushruta. Sushruta Samhita, Vaidya Jadavji Trikamji Aacharya and Naryana Ram Acharya edition 2nd Varanasi. Chaukhamba Surbharti Prakashana; 1990. Sutrasthanam Shonitvarniya Adhyaya 14/34

5. Kaviraj ambikadutta shastri-edtn 2nd chaukhmbha sanskrita samsthan Varanasi 2008 Susruta Samhita Sutra Sthana Jalaukavacharniya Adhyaya, 13: 4.

6. Sushruta. Sushruta Samhita. Text with English Translation \& Notes, Sutra Sthana, 1 st Ed. Varanasi: Chaukambha Visvabharati, 2004; 134-42.

7. Porshinsky BS, Saha S, Grossman MD, Beery II PR, Stawicki SP. Clinical uses of the medicinal leech: A practical review. J Postgrad Med, 201 1; 57: 65-71. 